\title{
Aesthestic Elements In Arabic Works Of Yoruba Authorship A Case Study Of Kitaab As-Shaghrab Of Tajul'adabi
}

\author{
HASHIMI A.O. (Ph.D) \\ Department Of Religious Studiesolabisi Onabanjo University, Ago-Iwoye, \\ Ogun State, Nigeria.
}

\begin{abstract}
There is no doubt that much work has been done in Arabic literature of Yoruba authorship and a kind of intellectual division of labour seems to have been obtained, but there is still a room for contributions. The personage that this paper intends to discuss his work-Kitaab as-shaghrab was one of the best speech actualizing icons emerged in $19^{\text {th }}$ century. The work is opened with what can be called didactic opening giving humility to people of scholarship. It presents to us with a bewildering variety of themes, as the quest for knowledge central in the work. Apart from moral issue raised, piety and ascetic life pervade the work. In the midst of the work the author buckled into a one to one correspondence with his opponents, where he made a catchy dismissive reaction. The work also deals with metaphysical issue which will continue to nag the questing mind. The work comes to a close with general humility from the author.This paper therefore intends to discuss the literary structure and stylistic devices employed in the Kitaab as shagrab. It discusses further the major themes encapsulated in the work and brings into fore its significance and impact on scholarship. Kitaab asshagrab reflects the life of the author and time he lived and people he met. The author was one of best speech actualizing icons and outstanding users of Arabic language, as he invested his best intellectual capital of Arabic language into the work.
\end{abstract}

Keywords: Taju'l-Adabi ,'Adid,Literary discussion,Humility

\section{INTRODUCTION}

Kitaab as-Shaghrab, which this paper intends to discuss commonly called 'Adidi, is one of the literary Arabic works of indigenous authorship by Yoruba scholar, who lived between the last quarter and first quarter of $19^{\text {th }}$ and $20^{\text {th }}$ centuries. It is a satirical work in verses directed against the uncultured "ulama of his time that were puffed by arrogance and jealousy. The work was composed in ornate words; therefore, it could only be comprehended by those who have mastery of Arabic language. The author employed different stylistic devices and rhetorical tropes to compose his poem. The author felt the need for skillful beginning (bara 'at al-Istihlai). This is achieved by abandonment of amatory prelude characteristic of classical Arabic poetry, rather he expressed nostalgia for people of scholarship and depicted what we can call paraenestic opening (an-Nasib). The author invested his best intellectual capital in the poem, this presents the author to us as one of the best speech actualizing icons and outstanding users of Arabic language, being a response to those that spurred him, puffed by arrogance to him and jealousy of him, he employed technical difficulty in the poems and demanded for its explanation from his opponents. Strange and ambiguous vocabularies were used in the work. The last of the stylistic features of the work is usage of rhetorical tropes. The author subjected his opponents to ridicule and cut them into size, this was done by the use of metaphor;

\subsection{About the Author}

His full name was Muhammad Ahmad b. 'Abd'li-Qadir b. Sahih, but popularly known with cynosure Tajul'Adab,( Bamgboye ,1987). His father 'Abd Qadir was Imam Imale from Masingba family in Balogun Ajikobi ward in Ilorin . (Hunwich,1995). Shaykh Tajul'Adab was born around 1885CE during the reign of Emir Ali b. Shitta who reigned between 1869 - 1891 C.E (Hunwich, 1995). The following poetic verse gives account of the real name of the author

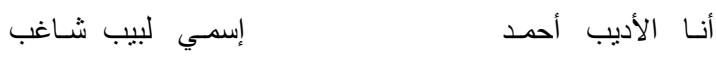

I am Ahmad, a literateur My name is Labibu Shaaghibu verse: 52

However, little was known about the early education of Shaykh Tajul 'Adab, but he might be possible to receive his Quranic studies from the feet of his father, who was one of the principal Imams in Ilorin. Nevertheless, it was conjectured that he had direct inspirational knowledge of Arabic and Islamic sciences, ( Hunwich, 1995) .while other opines that he was taken away by roaring wind for almost a decade where he 
acquired the skill of Arabic studies.Astronomy, (Hisab) Islamic mysticism (Tasawwuf), sermon (Wa'z), Admonition, (Nasihat) poetry (sh'ir) etc Shaykh embarked on preaching tour to many towns in Yorubaland such as Iwo, Ibadan and Abeokuta, and he was particularly successful at Abeokuta where he died and buried in 1923,(al- illuri,1978). As a mystical devotee who was not hunted by libidinal desires, he was inspired by moral aims, he combined Sufism with ducational activities, and according to al-illuri ( 1978), he brazed the trail of modernity in Arabic and Islamic studies in Yorubaland. He urged his followers and students (Murid) to acquire the knowledge of Islamic Sciences such as Arabic Grammar, (Nawh) etymology, (Sarf) Islamic jurisprudence (Fiqh) Sufism (Tasawwuf) etc. As a celebrated preacher and reformer, he founded an Islamic movement, named az-zumra al-Adabiyyah, a religious movement that combined Tasawwuf (Sufism) with educational activities. (Hunwich, 1995). Shaykh Tajul'Adab's works to a very large extent, are reflection of his life and time, therefore, understanding of his life require a survey of his works. Shaykh Tajul 'Adab was a prolific writer of remarkable standing; he authored some works that reflect his life time. The scope of his works covered Arabic grammar, Arabic etymology, morphology

\section{IITERARY STYLE OF KITAAB AS-SHAGHRAB : ’ ADID}

The work under study is a cryptic poem on decorum. It was composed by the author as a corrective measure to bully-cultured 'ulama who were puffed by arrogance to the author and jealousy of him. Kitaab asShaghrab commonly known as 'Adid is a mirror that reflects the life of the author and his time. The date of its composition is not known, but it is certain that it was composed during his preaching tour to some towns in Yoruba land. There are different versions of the work, found in different places such as Centre for Arabic Documentation, Institute of African Studies, University of lbadan. While other available in the market, published in Ilorin by Kewulere press. It is also available in the text of Mi'atay al-Qamus authored by Imam Abu Bakr al-Siddiq b. Salah al-Din Agbarigidoma, (1914 - 2001) Cairo 1400/1980, 33 - 44. A close examination of the available copies reveals that they are same work of one author. Kitab as 'Shaghrab contains fifty five (55) poetic verses of 110 hemistches. The copy at the Institute of Arabic Studies is catalogued under $\mathrm{CAD} / 352$, It has 4 folios and 8 lines per page with $21.5 \& 17 \mathrm{~cm}$ size. Each line or verse ends with letter $B a$ hence, it is called Qasidat Ba iyyah. It is written in brown ink in fine legible hand writing. The date of writing is not known. The verses are abundantly vocalized. It is necessary to point out that I relied on the copy published by Kewulere press, Ilorin. While the copy used in this research work was borrowed for photo-copy from Shaykh al-haji Ahmad Faozudin Alikinla Abdus Salam who resides in Ago-Iwoye Ogun State, Nigeria

\subsection{Title of the Work}

The title of the work is kitab as-Shaghrab which is commonly called 'Adid. The work derives its title from the verses of the poem. As a verse of the poem runs thus:

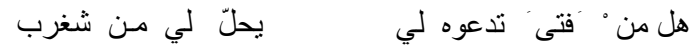

Is there anyone you could call for me to explain the brawled words? V: 49More again

$$
\text { عدّد إنشـاد الأرب }
$$

Enumerate number of poetic compositions of literateur Search by the seeker of knowledge. Verse: 1

The work derived its title Shaghrab and 'Adid from the above two verses

\subsection{Opening Line}

The work is opened with introduction, as the opening verse runs thus:

$$
\text { عدّد إنثــاد الأرب }
$$

Enumerate number of poetic compositions of literateur Search by the seeker of knowledge.

It was ancient practice of the Arab poets to begin their poems with erotic introduction. Here the author referred to literary efforts of scholars as a sign of humility and acknowledgement. 


\subsection{Content Analysis of the work.}

Kitab as Shaghrab contains a bewildering variety of themes, but admonition for quest for knowledge and certainty central in the poem. Apart from moral coda, moralization, scholarship, piety and ascetic life pervade the work. Among the subject matters addressed in the poem is long life, exaltation of pious Muslim women, caution against evil people and good mannerism.

\subsubsection{Prosodic metre:}

The prosodic metre employed in the work is basit. While the rhyme (qafiyyah) is Ba iyyah. Thus every verse ends with letter $B a$. The basit metre runs thus:

Mustaf'ilun faa'ilun mustaf'ilun faa'ilun: Mustaf'ilun faa'ilun mustaf'ilun faa'ilun

\subsubsection{Intellectual Contention:}

The author composed the poem as a response to the way some scholars treated him. It is a literary challenge, where he demanded for intellectual contest. As the following verses represent:

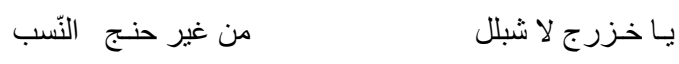

O! You a bush-cow (buffalo), you are neither related to a lion nor you related to a camel Verse: 24

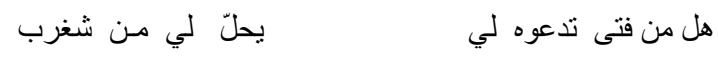

Is there anyone you could call for me? To explain the brawlled words Verse: 49

Here the author buckled into a one to one correspondence with his opponents

\subsubsection{Mystical or ascetic Approach:}

The author as a committed Sufi, demonstrated many Sufi traits in the work. These traits include reliance on God, (Tawwakkul) nearness to Allah through religious devotion (Qurb) rejection of worldly things (Zuhd) etc.

The following verses manifest such traits.

$$
\text { إنتي أداج خالقي }
$$

I worship my creator,Rather than seeking for worthless worldly materials verse: 26.

$$
\text { والسكسب جاز شاغبا كالمجد مسغرب }
$$

It is normal for servant of Allah to be hungry.Like strenuous servant of Allah is satisfied in state of hunger.

Verse: 42.

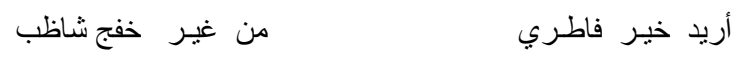

I seek for bounties of my creatorRather than worthless thing that makes one sad verse: 53.

\subsubsection{Religious Devotion}

The author lived a religious life full of commendation and emulation. Despite the hardship encountered by religious men of his age, he was pleased to serve Allah with commitment, as this was reflected in the verses of the poem.

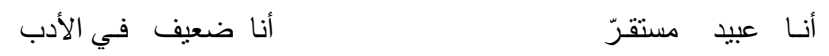

I am a petty servant who is fortified.I am indolent in the art of composition. Verse: 55

The author used the words" petty and indolent in a dissimulating language as manifestation of humility.

\subsubsection{Caution against evil people.}

The author expressed his distaste to evil people, he did not hide his feeling to avoid them and keep away from their company. As the verse of the poem runs thus:

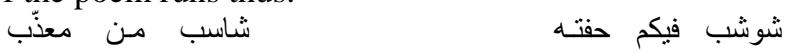


I fear the devilish people among you. The bite of scorpion suffices as punishment. verse: 51

\subsubsection{Exaltation of Muslim women}

The author exalted Muslim women and described them as fragrance of joy, while worldly women were condemned exbihiting stinking odour. The verse runs thus:

$$
\text { خمج هنو هذه }
$$

The unbelieving women emit steaking odour.And believing women radiate high-quality odour.

Verse: 27

\subsubsection{Moral Advice}

The author mentioned a set of guidelines for seekers of knowledge; these include humility, perseverance and submission. The following poetic verses serve as examples.

$$
\text { وإن دنيت مـهب }
$$

If you are drawn near to the path of Allah ay to the seeker of knowledge. Verse: 5

$$
\text { يدعج عين وسطه دعجـاء لا ليقرب }
$$

If you wish ask the custodian of knowledge A voice of seeker of knowledge (must) be trembling Verse: 16

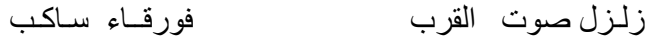

While a voice of mystic in the part of Allah (always) over whelming.(Because) His Guard is supernatural being that directs him. Verse: 7

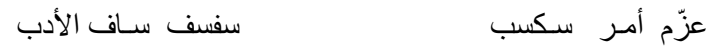

It is necessary to be resolute on religious matter. Whoever is not brisk at learning is insane. Verse: 9

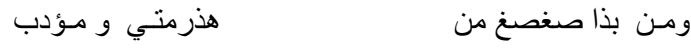

Who would be attentive to hear?My loquaciousness and wisdom.

Verse: 10

$$
\text { شنظب كلّ مطرب }
$$

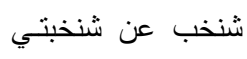

The path of knowledge is my path (Doctrine)It is a means of highness, greater than any other means of enjoyment Verse: 50

\section{SIGNIFICANCE OF THE WORK.}

The work understudy; kitab as-shaghrab depicts a feature of literary notion of humility which has formed a distinct feature in Arabic works of Yoruba authorship. The work is opened with humility and also closed with it. The author arrogated to himself as novice with shallow knowledge who is not skillful enough in the science of Arabic poetry. To say such thing amounted to self relegation which is a manifestation of humility that central in the work. Beyond this, the quality of the work is above the level of a novice or an ignorant person. It is further observed in the work that the author demonstrated the best of his intellectual capital in the poem. Of course, the author is one of the outstanding users of Arabic language and the best speech actualizing icons that dazzled the world with exceptional scholarship uncommon in our community. The composition of the poetic work is manifestation and reflection of the effects of the community of the author on him, his perceptions of phenomena around him as well as relationship with 'ulama of his time that he met. Therefore the work mirrors the attitudes, feeling and thoughts of people during the time of the author. It is also realized in the work that through the motifs and meaning encoded in the metaphors, the author revealed the unknown contents of his mind. He used metaphorical words to carve his ideas, for instance where he made catchy dismissive reaction and addressed his opponents as bush-cow, which is neither related to a lion nor it related to a camel. He further 
labelled them as snakes and scorpions.

The author also dealt with another metaphysical issue which will continue to nag the questing mind till the end of time, here the author declared that his actions were not of his own, but he was directed by supernatural being.

\section{CONCLUSION}

We have examined various aspects of kitaab as-saghrab which we studied in this paper. We now conclude this study by making a brief survey of the features of the workThe author brought the poem into an end with literary notion of humility. He referred to himself as petty and indolent in the literary task, but fortified on the path of God. This is a direct reflection of his cultural virtue of humility and irony of language usage as it is depicted in a popular usage which says ; "Emply vessel makes most sound"From the foregoing it is understood that this work under study is a great monument of research work. It is an invaluable literary legacy merits study and inquiry in all its ramifications. Its effect on Yoruba 'Ulama is very great and enormous. Its forms and contents are of high quality and can compare favorably with those of Hausaland in Nigeria in the period of the author. Therefore this work is recommended for further research work.

\section{REFERENCES}

[1] Al-illuri, Adam Abdullah: Islamic fi Naijiria. Agege press. Third edition, 1978/1398H.

[2] Bamgboye, Y.A "Contributions of Shaykh Taj al-Adab to Arabic and Islamic Learning in Yorubaland", aMaster's Dissertation, submitted to Department of Arabic and Islamic Studies, University of Ibadan. 1978

[3] Hunwick J.O: Arabic literature of Africa vol.2. The writing of central sudanic Africa. E.J, Brill. London 1995. PP. 444-468.

[4] Muhammad Labibu (Taju'l Adab): Kitaab as-saghrab in 'Salman Ake,B.O: kitaab as-saghrab: Adid Traslated into Yoruba language. Kewulere commercial press Ilorin. ( n.d)

[5] Research Bulletin: Centre of Arabic Documentation:institute of Arabic studies University of Ibadan. Vol. VI, no 1\&2, p.73 December 1970. 